\title{
Relationship of Wind Movement to Thermal Comfort at the Fencing House in Samarinda
}

\author{
Sukma Betariah ${ }^{1, *}$, Wahyu Setia Budi ${ }^{2}$, and Suzanna Ratih Sari ${ }^{3}$ \\ ${ }^{1}$ Program Magister Teknik Arsitektur, Universitas Diponegoro, Semarang, Indonesia \\ ${ }^{2}$ Departemen Fisika Fakultas Sains dan Matematika, Universitas Diponegoro, Semarang, Indonesia \\ ${ }^{3}$ Departemen Arsitektur Fakultas Teknik, Universitas Diponegoro, Semarang, Indonesia
}

\begin{abstract}
In fulfilling the thermal comfort level in the room can be carried out efforts to control the effect of climate on the building. In this case of wind and thermal comfort issues, passive control efforts, such as examples of the potential for air movement for ventilation and air exchange, are possible. The room of air movement is necessary because it plays an important role in achieving comfort in the room. While the temperature or humidity of the air inside the room is high, but there is sufficient air movement then the thermal comfort of the space can be achieved. The movement of air outside the building into space can also serve to cool the space. In addition, the movement of air can release heat from the surface of the skin through evaporative cooling (evaporative cooling). The greater the speed of air movement, the more heat that can be removed from the surface of the Human body. The purpose of this study is to examine the relation of wind movement to thermal comfort by connecting wind movement to thermal comfort in the fencing room to find out the cause and to produce good and convenient design concepts applied to fencing building in Samarinda. Quantitative data from the observation and measurement in the form of field data comparable with the theory, to obtain a thermal comfort findings at fencing in Samarinda.
\end{abstract}

Keywords: Air Movement, Thermal Comfort.

\section{INTRODUCTION}

In design of building should be able to make the occupants feel comfortable and comfort is an important factor to note.

According to Lippsmeier, ${ }^{6}$ Indonesia is included in wet tropical forest or wet tropical covering the area around the equator to about 150 North and South. The character of this season is marked by precipitation (rain) and high humidity with almost always high temperatures (annual temperatures ranging from $23{ }^{\circ} \mathrm{C}$ to $38{ }^{\circ} \mathrm{C}$ in summer), in relation to this climate convenience is thermal comfort. Comfort in relation to buildings can be defined as a situation where it can provide a comfortable and pleasant feeling for its inhabitants. Comfort achieved when in certain air conditions, certain wind speeds produce a balanced body evaporation process (Juhana, 2001).

The most basic indicator used for comfort is air temperature. Although an important indicator to be taken into account, air temperature alone is not a valid or accurate indicator to express comfort. Air temperature should always be considered in relation to physical environmental factors and personal and other aspects (Idham NC, 2016).

These factors may not be related to each other, but together contribute in comfort. These environmental factors include air

${ }^{*}$ Author to whom correspondence should be addressed. temperature, radian temperature, air velocity and humidity, while personal factors include clothing insulation and metabolism.

Some of the criteria of tropical building design are the shape and floor plan should be rectangle where the long side faces north south with enough openings in this direction, thin building to ensure air circulation cross, ventilation holes are located opposite. Wide openings about $20 \%$ of wall area. Apical openings as ventilation and lighting.

While the sense of the wind is a movement air. The wind driving force is the force that causes air to move. In the building group configuration, open buildings with sufficient space between buildings to ensure air circulation and have continuous alleys to drain the wind. Air movement causes heat release from the skin surface by evaporation. The sooner, the more heat is lost.

Air movement occurs when there is a change in temperature, the wind that flows from low temperature areas to high temperatures. In humid tropics, wind is needed to reduce temperature and humidity. The desired air movement is the surf, at speeds up to $1 \mathrm{~m} / \mathrm{sec}$. Wind movement in the settlement scale is determined by the density as well as the pattern of the building group. In the home scale is determined by the form of mass, width and location of ventilation, spatial and vegetation around the building. ${ }^{6}$

In the context of response to tropical climate, the building is considered good if it can change the condition of the external 


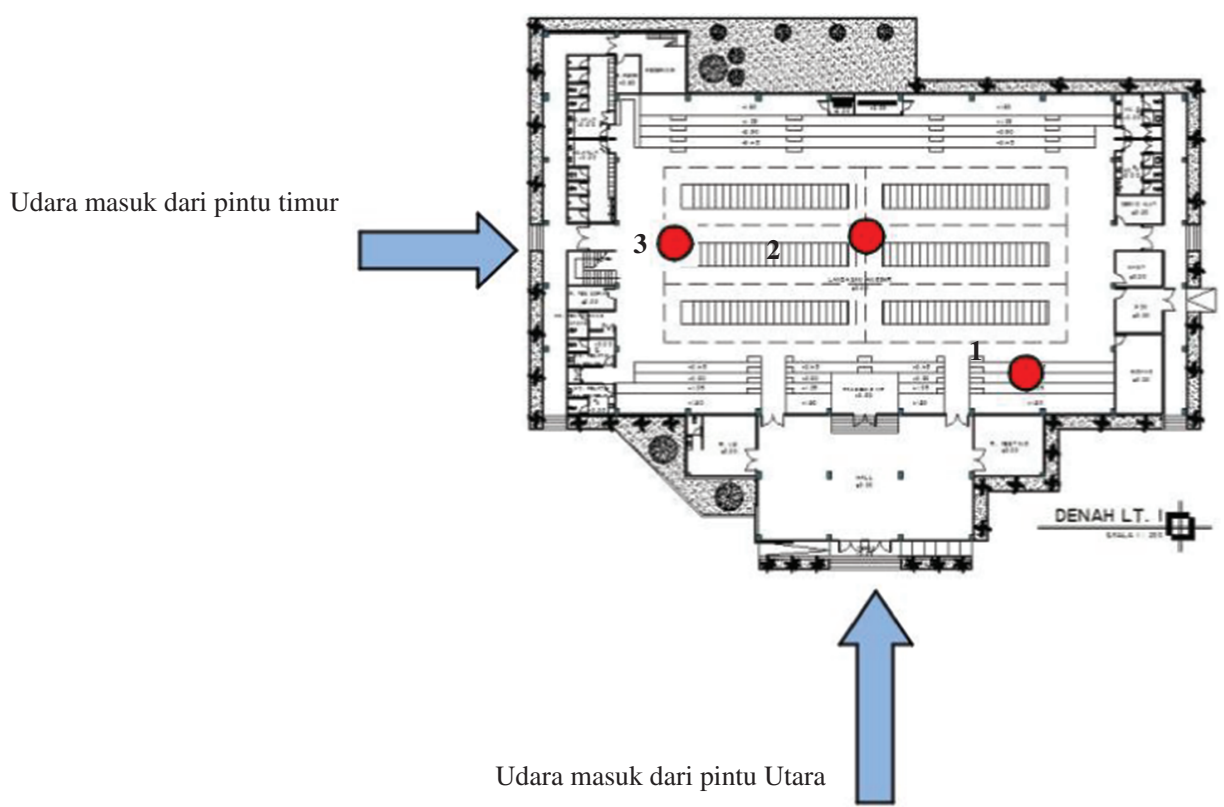

Fig. 1. Floor plan 1 for point 1, 2 and 3 .

climate is relatively uncomfortable for humans who live in the building.

The fencing house is a place that facilitates special fencing games. Fencing hall space or called Fencing hall is a space to practice fencing with the necessary equipment such sport.

The Fencing House in Samarinda is the first fencing building in Indonesia and in ASEAN, in 2010, with a capacity of 300 users, be it a player or a spectator.

This building is located on AW. Syahrani street, Air Hitam polder, Samarinda Ulu Sub-district, Samarinda City, East Kalimantan. Floor fencing building area $\pm 2.008,2 \mathrm{~m}^{2}$. The fencing building has two storey. For all main activities (spatial, spectator area, referee room, toilet, warehouse, health room, meeting room, management room, VIP, and Hall. It is on first floor.

The fencing is in front of the water folder, this building stands at an area that has good wind potential, has orientation of building facing north. While on the 2nd floor consists of cafeteria and cafe manager.

At the beginning of the planning of this building is designed as a building uses $\mathrm{AC}$ assistance is central air conditioning, but after the implementation to date it turns out the fencing building

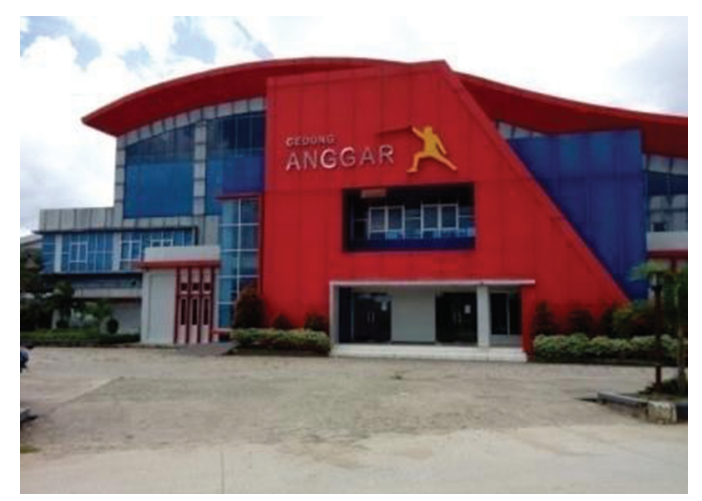

Fig. 2. Front view of the fencing house. is not equipped with air conditioning facilities, due to lack of budget for the purchase of central air conditioning. Though for the clothing Athlete fencing that has 3 layers, because it is in the building is very need comfort when doing the activity. This is what makes researchers to make observations and research.

The purpose of this research is to study the relation of wind movement to thermal comfort in fencing room of Samarinda fencing building, influencing variable are wind, temperature and humidity.

\section{EXPERIMENTAL DETAILS}

The method to be used in this study are by comparing several measurements of air velocity measured directly to three different measuring points or measuring positions in the middle of the field and in the area of the canon) with the condition of the eastern door and the open hall door.

\section{RESULTS AND DISCUSSION}

These data collection are conducted on April 13, 2017, start at 08.00 WITA until 17.00 WITA, the data obtained are as follows.

Table I. Effective temperature measurement and wind at point 1 (one).

\begin{tabular}{lcccccc}
\hline No. & Time & Temperature $\left({ }^{\circ} \mathrm{C}\right)$ & $\begin{array}{c}\text { Humidity } \\
(\%)\end{array}$ & $\begin{array}{c}\text { Wet } \\
\text { temp. }\left({ }^{\circ} \mathrm{C}\right)\end{array}$ & $\begin{array}{c}\text { Wind } \\
(\mathrm{M} / \mathrm{S})\end{array}$ & $\begin{array}{c}\text { Effective } \\
\text { temp. }\left({ }^{\circ} \mathrm{C}\right)\end{array}$ \\
\hline 1 & 08.00 & 29,7 & 73,4 & 25,71 & 0,23 & 27,2 \\
2 & 09.00 & 32,3 & 68,1 & 27,0 & 0,23 & 28,9 \\
3 & 10.00 & 34,5 & 57,4 & 27,15 & 0,23 & 29,6 \\
4 & 11.00 & 31,2 & 57,9 & 24,48 & 0,24 & 27,2 \\
5 & 12.00 & 36,0 & 53,0 & 27,61 & 0,20 & 30,1 \\
6 & 13.00 & 33,1 & 57,6 & 26,06 & 0,54 & 28,8 \\
7 & 14.00 & 38,6 & 47,1 & 27,95 & 0.47 & 31,8 \\
8 & 15.00 & 33,8 & 59,1 & 26,95 & 0.29 & 29,1 \\
9 & 16.00 & 33,3 & 61,3 & 26,93 & 0.49 & 29,1 \\
10 & 17.00 & 32,3 & 68,4 & 26,98 & 0,39 & 28,8 \\
\hline
\end{tabular}


Table II. Effective temperature and wind measurement at point 2 (two).

\begin{tabular}{lcccccc}
\hline No. & Time & Temperature $\left({ }^{\circ} \mathrm{C}\right)$ & $\begin{array}{c}\text { Humidity } \\
(\%)\end{array}$ & $\begin{array}{c}\text { Wet temp. } \\
(\mathrm{M} / \mathrm{S})\end{array}$ & $\begin{array}{c}\text { Wind } \\
\left({ }^{\circ} \mathrm{C}\right)\end{array}$ & $\begin{array}{c}\text { Effective } \\
\text { temp. }\left({ }^{\circ} \mathrm{C}\right)\end{array}$ \\
\hline 1 & 08.00 & 29,5 & 70,9 & 0,30 & 24,74 & 26,6 \\
2 & 09.00 & 30,7 & 65,9 & 0,31 & 24,82 & 27 \\
3 & 10.00 & 32,7 & 58,6 & 0,32 & 25,9 & 28,2 \\
4 & 11.00 & 30,8 & 56,7 & 0,56 & 23,91 & 26,8 \\
5 & 12.00 & 34,8 & 55,2 & 0,24 & 27,05 & 29,5 \\
6 & 13.00 & 34,8 & 54,7 & 0,55 & 26,95 & 29,2 \\
7 & 14.00 & 35,8 & 49,5 & 1,00 & 26,7 & 29,4 \\
8 & 15.00 & 33,8 & 57,9 & 0,77 & 26,72 & 29 \\
9 & 16.00 & 33,0 & 67,9 & 0,72 & 26,67 & 29 \\
10 & 17.00 & 32,4 & 63,1 & 0,93 & 26,47 & 28,8 \\
\hline
\end{tabular}

Position point 1 in the audience area, located next to the hall door. In Table I, from 08.00 to 10.00 , there can be an effective temperature rise with the same wind speed, but after 11.00 there is a decrease in temperature effective temperature due to the increase in wind speed, then after that at 12.00 the wind speed decreases to $0,20 \mathrm{~m} / \mathrm{s}$ to make the effective temperature to be high up to $30{ }^{\circ} \mathrm{C}$. Then at 13.00 , the wind speed rises up to $0.54 \mathrm{~m} / \mathrm{s}$, thus making the effective temperature fall, after which at 14.00 the effective temperature becomes increased again when there are decreased in wind speed. From 15:00 to 17:00, the effective temperature starts to decrease with the faster wind speed.

Point 2 is in a matching area right in the middle of the field, until the wind is obtained directly from the east door and the hall door. In Table II, it can be seen from 08.00 to 10.00 that the effective temperature of the day increases, with a stable wind densityof 0.30 , after which at 11.00 with an increased wind speed keeps the temperature down to 26.8 , but when speed wind down, effective temperature becomes high again.

The position of point 3 is near the east door. In Table III, starting at 08.00 to 09.00 experiencing the effective temperature and the same wind speed, at 10.00 the wind speed drops until the effective temperature becomes high, then at 11.00 the wind speed rises and makes the temperature effective be down.

With regard above, the effective temperature will decrease if the room has a high wind speed or the presence of air movement in the chamber, but when the effective temperature

Table III. Effective temperature and wind measurement at point 3 (three).

\begin{tabular}{lcccccc}
\hline No. & Time & Temperature $\left({ }^{\circ} \mathrm{C}\right)$ & $\begin{array}{c}\text { Humidity } \\
(\%)\end{array}$ & $\begin{array}{c}\text { Wet } \\
\text { temp. }(\mathrm{M} / \mathrm{S})\end{array}$ & $\begin{array}{c}\text { Wind } \\
\left({ }^{\circ} \mathrm{C}\right)\end{array}$ & $\begin{array}{c}\text { Effective } \\
\text { temp. }\left({ }^{\circ} \mathrm{C}\right)\end{array}$ \\
\hline 1 & 08.00 & 29,9 & 70,1 & 0,40 & 25,43 & 27,2 \\
2 & 09.00 & 30,5 & 66,5 & 0,40 & 25,37 & 27,2 \\
3 & 10.00 & 32,5 & 58,7 & 0,38 & 25,75 & 28,2 \\
4 & 11.00 & 30,9 & 55,5 & 0,58 & 23,78 & 26,8 \\
5 & 12.00 & 32,2 & 54,8 & 1,15 & 24,75 & 27,5 \\
6 & 13.00 & 35,0 & 55,9 & 0,57 & 27,36 & 29,8 \\
7 & 14.00 & 34,3 & 55,7 & 0,94 & 26,72 & 29,2 \\
8 & 15.00 & 33,6 & 59,3 & 0,98 & 26,82 & 29 \\
9 & 16.00 & 33,0 & 62,1 & 0,95 & 26,82 & 29 \\
10 & 17.00 & 32,3 & 64,1 & 1,22 & 26,56 & 28,6 \\
\hline
\end{tabular}

will rise, the wind speed down/small or the absence of air movement.

\section{CONCLUSION}

From the building data and also the wind data obtained greatly affect both the bad work of a tropical architecture measured quantitatively. In this way, residents or building users are expected to be more comfortable when compared to when they are outdoors.

From the data above, can be seen the relationship between air movement with thermal comfort where the faster/stronger movement of air in the room then the effective temperature becomes down so that thermal comfort will be achieved.

In Building Fencing sports. A very good wind potential because the building is in front of the water folder. Researchers have 3 ideas solution. There are:

Fencing buildings should preferably have many openings or ventilation, so that the potential utilization of wind around the building can be more leverage and the movement of the wind that flows into the space will be very comfortable without having to with the help of artificial air conditioner such as air conditioner or blower.

The second solution is the theory about wind direction techniques with wall fins. The author suggests using the technique of directing the wind (find walls) into the chamber. The found wall fins can significantly improve ventilation through the installation of windows and vents on the same side of the wall in a building. This is done to change the distribution of wind pressure to maximize.

While the third solution, the authors suggest to change the roof model by using the chimney effect of the roof, where the chimney effect can remove air from inside the building with natural convection action, this chimney will dispose of hot air even though there is a difference in temperature in the inner space is greater than the difference outside room temperature and another vertical holes.

Acknowledgments: This work was supported in part by Magister of Architecture, Diponegoro University.

\section{References and Notes}

1. T. H. M. Frick and Heinz, Arsitektur Ekologis, Kanisius dan Soegijapranata University Press, Yogyakarta (2006)

2. H. dan Sukawi Gagoek, Jurnal Modul 14 (2014).

3. Juhana, Arsitektur Dalam Kehidupan Masyarakat, Bendera, Semarang (2011).

4. F. Kurniawan, Mengenal Cabang Olahraga Klasik, Yogyakarta University State, Anggar (1996).

5. N. Lechner, Heating, Cooling, Lighting, PT, Raja Grafindo Persada, Jakarta (2007)

6. G. Lippsmeier, Bangunan Tropis, Penerbit Erlangga, Jakarta (1994).

7. Y. B. Mangunwijaya, Pengantar Fisika Bangunan, Penerbit Djambatan, Jakarta (1994).

8. A. Marsh, Performance Analysis and Conceptual Design, This thesis is presented for the degree of, Australia: University of Western Australia (1997)

9. T. Priambodo and B. E. Mordaka, Fisika Dasar, Andi Yogyakarta, Yogyakarta (2009)

10. P. Satwiko, Fisika Bangunan, Penerbit Andi, Yogyakarta (2009).

11. Sangkertadi and Suryono, Mengestimasi koefisien bukaan Cd pada jendela bangunan tinggi dengan bantuan simulasi CFD, dimensi teknik arsitektur, Desember (2001), Vol. 29, pp. 147-150. 